\title{
AKTUALISASI KARAKTER ALLAH DALAM MENYELAMATKAT MANUSIA
}

\author{
Oleh : Pdt. Daniel Rumaikewi, S.Th., M.Th \\ Sekretaris Prodi Magister Kepemimpinan Kristen (M.Ag)
}

\begin{abstract}
ABSTRAK
Keselamatan adalah harapan dan dambaan setiap umat manusia dan merupakan topik yang menarik dan paling mendasar dari iman Kristen karena kesematan meliputi dua aspek penting yang berhubungan dengan kehidupan, yaitu keselamatan hidup dimasa kini dan masa yang akan datang (kehidupan kekal). Namun apabila diperhadapkan pada pertanyaan tentang kepastian keselamatan, maka seringkali ada respon keraguan yang terlihat dan terdengar sebagai jawaban. Respon keraguan itu terafiliasi dengan konsep yang berpandangan bahwa keselamatan hidup manusia dapat hilang apabila dia melakukan dosa. Allah didalam kekekalan telah merencanakan dan berkaya dalam menyelamatkan manusia. Kualitas dari karya Allah Tritunggal didasari oleh hati-Nya yang penuh belas kasihan.

Kata kunci: Keselamatan, kualitas, karya, Allah Tritunggal
\end{abstract}

\section{Kata Kunci : Aktualisasi, Karakter Allah, Menyelamatkan Manusia}




\section{A. PENDAHULUAN}

Keselamatan adalah harapan dan dambaan setiap umat manusia dan merupakan topik yang menarik dan paling mendasar dari iman Kristen karena keselamatan meliputi dua aspek penting yang berhubungan dengan kehidupan, yaitu keselamatan hidup dimasa kini dan masa yang akan datang (kehidupan kekal). Namun apabila diperhadapkan pada pertanyaan tentang kepastian keselamatan, maka seringkali ada respon keraguan yang terlihat dan terdengar sebagai jawaban. Respon keraguan itu terafiliasi dengan konsep yang di anut oleh aliran Armenianisme yang berpandangan bahwa keselamatan hidup manusia dapat hilang apabila dia melakukan dosa. Pandangan yang mendasari keyakinan ini adalah bahwa Allah memilih seseorang berdasarkan kehendak bebas orang tersebut. Manusia dalam ketidakmampuan akibat dosa tidak dapat memilih Allah, tetapi Allah memberikan kepada manusia itu suatu anugerah khusus yang menghilangkan pengaruh dari kejatuhan manusia dan memungkinkan manusia untuk membuat pilihan mereka berdasarkan kehendak bebasnya.

Suatu kekeliruan yang dianggap benar sebagai suatu doktrin dalam Arminianisme adalah bahwa manusia memiliki kewenagan lebih atas tindakannya untuk memilih dari pada kedaulatan Allah dan membuat Allah tunduk kepada tindakan manusia dan bukannya manusia tunduk pada tindakan Allah. Banyak denominasi telah mengadopsi teologi Arminian, termasuk John dan Charles Wesley yang mendirikan gereja Metodis, Pentakosta dan kebanyakkan gereja karismatik, Sidang Jemaat Allah, Gereja Nazarene, Mennonite, Advent Hari Ketujuh, Bala Keselamatan, Christian \& Missionary Alliance dan banyak kelompok Baptis. Ini akan aman untuk mengatakan bahwa teologi Arminian merupakan unsur dominan dalam kebanyakkan gereja Kristen saat ini, dan pandangan Calvinis telah ditolak atau diabaikan.Ada pertentangan yang intensif terjadi di dalam gereja atas isu ini, khususnya tentang pusat dari keselamatan manusia yaitu pada kedaulatan mutlak Allah atau pada kehendak bebas manusia. Sebaliknya pandangan teologi Calvinis menyatakan bahwa keselamatan hidup kekal ada pada kedaulatan Allah.

Adanya pertentangan intensif di dalam gereja atas topik ini yang sesungguhnya melatar belakangi penelitian terhadap kesetaraan kualitas karya Allah Tringgal. Pertentangan akibat perbedaan konsep dan 
gagasan itu pada dasarnya adalah suatu yang wajar, namun dibalik kewajaran itu sesungguhnya dapat menimbulkan pemahaman yang salah terhadap iman Kristen yaitu percaya kepada Yesus Kristus sebagai Tuhan dan Juruselamat yang pada akhirnya dapat menjadi sarana lahirnya ajaran-ajaran yang sesat. Ada banyak buku dan tulisan yang mungkin telah membahas topik ini, tetapi hal penting yang perlu dikaji lebih dalam adalah puncak dari rencana penyelamatan itu yaitu kematian Yesus Kristus di kaya salib menjadi korban tebus, sehingga tujuan yang hendak dicapai dari penelitian terhadap kesetaraan kualitas karya Allah Tritungal adalah memberikan penjelasan dan penegasan yang utuh dari Alkitab tentang siapa Allah, apa saja yang dilakukan oleh Allah, bagaimana sesungguhnya kualitas dari karya Allah Tritunggal dan apa sesungguhnya makna dari karya Allah Tritunggal.

\section{B. PENEGASAN ALKITAB TENTANG ALLAH}

Berpikir dan berbicara tentang Allah adalah upaya yang dilakukan oleh manusia dalam rangka pengenalan akan Allah yang sempurna. Namun perlu disadari bahwa upaya atau usaha manusia tidak dapat dilakukan dengan mengandalkan pikirannya sendiri oleh karena sesungguhnya manusia itu terbatas. J. Dwight Pentacost mengungkapkan bahwa tidak ada aktivitas pemikiran yang lebih tinggi dari pada aktivitas pemikiran yang berusaha untuk pengetahuan tentang Allah dan manusia tidak bisa mendapatkan pengetahuan tentang Allah dengan mengandalkan pikiranya sendiri. ${ }^{1}$ Keterbatasan dan keingintahuan manusia tentang Allah seringkali tidak berjalan seimbang dan menimbulakan berbagai macam pandangan serta konsep tentang Allah yang salah dan menjadi embrio dari ajaran-ajaran yang menyesatkan. Aspek lain yang juga sangat mempengaruhi dan merupakan problem yang sangat serius bagi manusia dalam upaya memahami Allah adalah kemajuan atau perkembangan ilmu pengetahuan serta majunya cara berpikir manusia.

Upaya manusia untuk memiliki pengetahuan tentang Allah adalah bukan sekedar mendapatkan pengetahuan bahwa Allah itu ada, tetapi juga kemudian harus dapat dipahami apa yang wajib kita ketahui

${ }^{1}$ Paul Enns, "Kata Pengantar," The Moody Handbook Of Theology (Malang: Literatur SAAT, 2004), hlm. ix. 
tentang Dia, apa yang berguna untuk kemuliaan-Nya atau dapat dikatakan bahwa pengetahuan akan Allah harusnya mengasuh kita untuk hidup takut pada-Nya dan mempermuliakan-Nya. ${ }^{2}$ Pengetahuan tentang Allah tidak sekedar mengetahui bahwa Allah adalah pencipta, penggerak utama, yang ada dalam kekekalan, tetapi hendaknya pengetahuan tentang Allah meliputi seluruh aspek karakteristik dari Allah dan juga karya-karya-Nya.

Sumber utama pengetahuan tentang Allah dalam iman Kristen adalah Alkitab. Alkitab bukan sekedar buku yang berisi firman Tuhan tetapi adalah Firman Allah, yaitu perkataan Allah yang diilhamkan oleh Roh kepada setiap penulis untuk menulisnya, dijaga dan diawasi dengan ketat oleh Roh.

\section{Keberadaan Allah}

Berbicara tentang keberadaan Allah, itu berarti kita akan dan sedang berbicara tiga pertanyaan penting yang berhubungan dengan Allah yaitu siapa Allah, kapan Allah ada dan bagaimana cara keberadaanya. Iman Kristen meyakini bahwa Allah itu tidak terbatas dan oleh karena itu dari keyakinan itulah harusnya kita yakini bahwa ada suatu masa yang tak berawal dan berakhir yang di dalam masa itu ada aktifitas atau gerakan/aksi yang dilakukan dan bahwa didalam aktifitas/gerakan/aksi itu tidak ada sesuatu yang dapat membatasinya. Dengan keyakinan-keyakinan inilah dan di dalam keterbatasan dan ketidakmampuan kita sebagai manusia dan oleh anugerah Allah yang telah menyatakan diri-Nya bagi manusia, kita dapat megetahui dan memahami Allah dengan baik dan benar.

\section{a. Pribadi Yang Ada Dengan Sendirinya}

Keberadaan Allah sebagai pribadi yang ada dengan sendirinya mengandung pengertian bahwa dalam suatu masa yang berawal dan berakhir yang disebut kekekalan Allah ada. Keberadaan Allah adalah Allah sendiri, artinya bahwa tidak ada sesuatu yang ada sebelum Allah dan Allah tidak diciptakan oleh sesuatu yang ada terdahulu. Pribadi

${ }^{2}$ W. F. Dankbaar, "Calvin," Jalan Hidup Dan Karyanya (Jakarta: Badan Penerbit Kristen, 1976), hlm. 153-154. 
yang ada dengan sendirinya menunjukkan bahwa Allah adalah pribadi yang berdaulat dan berkuasa. Ia berkuasa atas masa atau waktu, dapat melakukan apapun berdasarkan kedaulatan-Nya dan tidak dapat dibatasi oleh apapun juga seperti penegasan dalam Alkitab Kejadian 1:1 "Pada Mulanya Allah menciptakan langit dan bumi" dan Yohanes 1:1 "Pada mulanya adalah Firman; Firman itu bersama-sama dengan Allah dan Firman itu adalah Allah."

Dieter Beker dalam bukunya Pedoman Dogmatika mengatakan bahwa "Allah memperkenalkan diri-Nya sebagai yang selalu akan ada, tetapi juga sebagai sesuatu yang akan ada dalam bentuk yang Ia pilih sendiri dari waktu ke waktu. ${ }^{3}$ Sebagai pribadi Allah memiliki ciri psikologi seperti Allah memiliki pikiran, perasaan dan memiliki kehendak. Dengan ciri-ciri ini Allah berinisiatif dalam menyatakan diriNya kepada manusia tanpa dibatasi oleh apapun juga yang disebut dengan penyataan umum dan penyataan khusus.

\section{b. Allah Itu Roh}

Ada begitu banyak nama dan sebut yang diberikan untuk menyebut atau menyatakan siapa Allah, tetapi Alkitab dengan tegas dan jelas menyatakan bahwa Allah adalah Roh. R. A. Woolley mengatakan bahwa "Allah adalah Roh yang perlu dipahami sebagai roh yang sejati dalam pengertian bahwa Ia bukanlah kumpulan atau terdiri dari bagianbagian melaikan tanpa tubuh dan tak dapat dilihat dengan panca indera. ${ }^{4}$ Pemahaman terhadap Allah sebagai Roh yang sejati memberikan pengertian bahwa sesungguhnya Allah bukan manusia, dan juga benda. Alkitab menggunakan dua kata untuk menjelaskan hal ini yaitu ruakh dan pneuma.

\section{c. Allah Tritunggal}

Patut diakui bahwa salah satu doktrin yang sampai saat ini masih menjadi perdebatan dan menjadi sumber kritikan terhadap iman Kristen

\footnotetext{
${ }^{3}$ Theol Bakers, “Allah,” Pedoman Dokmatika (Jakarta: BPK Gunung Mulia, 2000).

${ }^{4}$ R. A. Woolley, "Allah adalah Roh Sejati," dalam Ensiklopedi Alkitab Masa Kini, pen., J. M. Pattiasina (Jakarta: Yayasan Komunikasi Bina Kasih/OMF, 2004), hlm. 33.
} 
adalah doktrin tentang keTritunggalan Allah atau Trinitas. Istilah Tritunggal atau Trinitas memang tidak terdapat dalam Alkitab, namun penggunakaan istilah ini sudah ada sejak abad 2 dan diterima dalam teologi Kristen pada abad 4 serta mengalami perkembangan pemikiran atau konsep yang lebih jelas oleh Irenaeus dari Lyon dan Tertulianus.

Istilah Tritunggal atau Trinitas memang tidak dapat diterjemahkan dalam berbagai pengertian bahasa bahkan untuk menganalogikan istilah ini tidaklah dapat dipahami dengan benar. Hal yang benar adalah mengerti istilah ini dari apa yang di tulis dalam Alkitab berdasarkan penyataan diri Allah pada masa Perjanjian Lama dan Perjanjian Baru. Salah satu ayat yang digunakan untuk menyatakan konsep Tritunggal atau Trinitas adalah kitab Kejadian 1:26: Berfirmanlah Allah "Baiklah Kita menjadikan manusia menurut gambar dan rupa Kita, supaya mereka berkuasa atas ikan-ikan di laut dan burung-burung di udara dan atas ternak dan atas seluruh bumi dan atas segala binatang melata yang merayap di bumi."

Dalam PL Allah seringkali berbicara atas nama diri-Nya sendiri dengan memakai kata-kata yang menunjukkan jamak. Dalam teks אֶֶלהִים adalah kata yang digunakan Allah untuk menyatakan siapa diri-Nya. Kata ini dalam pengertian umum menyatakan atau berhubungan dengan jumlah/angka dan diterjemahkan dalam bahasa Inggris "God" yang berarti Tuhan. Oleh karena terjemahan kata ini menunjuk kepada Tuhan, maka seringkali disalah persepsikan oleh orang bahwa agama Kristen percaya kepada tiga Tuhan. Kata ini jika ditelusuri dalam berbagai bahasa yang dugunakan dalam Perjanjian Lama mempunyai pengertian dan penekanan yang sama sebagaimana dijelaskan oleh R. אֶֶהים Laird Harris bahwa dalam bahasa Ugarityc menggunakan kata (elohim) yang diartikan Tuhan dalam bentuk jamak, dalam bahasa Phonesia memakai kata אל (im) dan dalam bahasa Aramic memakai kata אֶלֵ אֶלה (elah) yang bentuk jamaknya (elahyim). ${ }^{5}$ Dengan demikian kata "kita' tidak sedang menunjukkan bahwa ada tiga Allah tetapi lebih menunjukan pada satu kesatuan dari pribadi-pribadi yang berbeda, artinya Allah itu esa tetapi terdiri dari tiga pribadi. Benjamin

5. אמלהים," dalam Theological Word Old Testament (Chicago: Moody Press, 1980), hlm. 93. 
Davidson menjelaskan bahwa אֶלהים (elohim) adalah bentuk kata jamak yang mutlak. ${ }^{6}$

Dalam Perjanjian Lama Ketritunggalan Allah hanya bersifat tersirat, namun berbeda hal dengan apa yang bentangkan dalam Perjanjian Baru bahwa yang tersirat dala PL dinyatakan dengan terang benderang dalam PB. Beberapa ayat Firman Tuhan berikut akan menjelaskan apa yang tersirat itu seperti dalam Injil Matius 3:16-17 bahwa ada tiga pribadi yang tergambar dalam percakapan pada peristiwa pembaptisan Tuhan Yesus, yaitu ada satu pribadi yang dibaptis, ada satu pribadi yang bersuara dan menyebut yang dibaptis sebagai anak yang mengindikasikan bahwa pribadi itu adalah Bapa dan ada pribadi dalam rupa burung merpati yang diutus untuk menyertai anak dalam menunaikan tugas pekerjaan dari Bapa. Dalam bahasa Yunani ada tiga kata yang dipakai untuk menjelaskan ketiga pribadi itu,

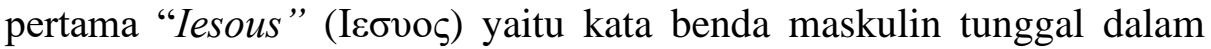
bentuk nominatif yang menunjuk sebagai subyek kalimat dengan artikel ó menunjuk dan menjelaskan identitas dari subyek, dengan demikiain dapat dikatakan bahwa subyek kalimat adalah satu pribadi. ${ }^{7}$ Kata kedua adalah Pneuma (Pnevuma)adalah kata benda dalam bentuk netral tunggal dengna bentuk akusatif yang menunjukkan obyek langsung dengan artikel to menjelaskan idetintas diri dari obyek, sehingga dapat disimpulkan bahwa obyek kalimat adalah satu pribadi. $^{8}$ Kata ketiga adalah Mou $\mu о v$ adalah kata ganti orang pertama tunggal yang berasal dari kata "ego" yang artinya aku, ku dengan bentuk kasus adalah generif yang menyatakan kepemilikan. Dalam Tafsiran Alkitab Masa Kini, R. E. Nixon menjelaskan bahwa peristiwa pembaptisan itu Yesus melihat Roh yang adalah satu pribadi dan juga mendengar suara dari Allah yang juga menunjuk pada satu pribadi. ${ }^{9}$

Dalam ayat Firman Tuhan, Injil Matius 28:19, Yesus memerintahkan murid-murid untuk pergi dan jadikan semua bangsa murid serta membaptis mereka di dalam nama Bapa, Anak dan Roh

6"אלהִים Benjamain Davidson, dalam The Analitycal Hebrew and Chaldee Lexicon (Michigan: Zondervan Publising House, 1980), hlm. 28.

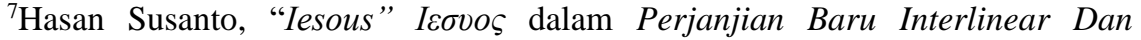
Konkordasi (Jakarta: Lembaga Alkitab Indonesia, 2004), hlm. 2:12.

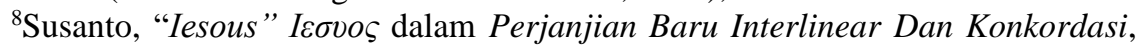
hlm. 651 .

${ }^{9}$ R. E. Nixon, Tafsiran Alkitab Masa Kini, pen., H. P. Nasution (Jakarta: Yanyasan Komunikasi Bina Kasih/OFM, 1999), hlm. 68-69. 
Kudus. Ada tiga nama yang disebutkan oleh Tuhan Yesus dan menunjukkan tiga pribadi yang berbeda, karena dalam kamus bahasa Indonesia arti kata "Nama" menjelaskan ciri tertentu atau identitas dari seseorang yang dalam bahasa Yunani menggunakan kata "Onoma" yang mempunhyai arti nama atau orang yang menjelaskan kepemilikan. Allah Bapa.

Dalam Perjanjian Lama kata Allah Bapa banyak dikenal sebagai Allah. Kata Allah Bapa adalah sebuah ungkapan yang ditujukan bagi suatu pribadi dari Tritunggal untuk menyatakan suatu hubungan yang erat atau menyatakan kedekatan dan keakraban. Di dalam kitab Injilinjil. dalam berbagai pengajaran Yesus seringkali menggunakan ungkapan Allah Bapa untuk menyatakan hubungan yang begitu dekat berhubungan, hal ini erat hubungannya dengan sifat-sifat Allah, dimana Allah sebagai Bapa yang mengutus-Nya. Kata ini digunakan sebanyak 245 kali dalam Perjanjian Baru, sebagaimana Firman Tuhan berikut: "Tidak ada seorangpun yang datang kepada-Ku jikalau ia tidak ditarik oleh Bapa yang mengutus Aku. dan ia akan Kubangkitkan pada akhir zaman."

Menurut Donald Guthrie, ajaran kebapakan Allah adalah ajaran yang membedakan bagaimana orang Kristen yang menyembah Allahnya dengan suasana yang harmonis dibandingkan dengan penyembahan yang dilakukan oleh orang-orang pada saat itu terhadap dewa-dewanya dengan penuh ketakutan. ${ }^{10}$ Dijelaskan juga bahwa gagasan kebapakan Allah, telah ada pada masa Perjanjian Lama, namun gagasan itu dipakai sebagai Bapa umat-Nya. Allah diangggap sebagai Bapa orang Israel dalam arti sebagai suatu bangsa.

Jadi dapat dikalakan bahwa ungkapan Bapa adalah ungkapan yang menyatakan begitu perhatiannya Allah sebagai pencipta terhadap anakanaknya (orang percaya). Allah Anak (Yesus Kristus). Tak dapat dipungkiri oleh kita jika berbicara Kristus adalah Allah merupakan dan menjadi persoalan yang selalu mendapat sorotan dan kritikan. Oleh karena itu penulis berpendapat bahwa untuk menjelaskannya harus dibicarakan secara luas dalam hal ini mencakup kehadiran-Nya serta tujuan kehadiran-Nya. Kehadiran Yesus di dunia memang menjadi persoalan berhubungan dengan pengakuan iman Kristen bahwa Yesus adalah Allah, namun Alkitab dengan jelas memberi keterangan bahwa

${ }^{10}$ Donald Guthrie, “Allah Sebagai Bapa," Teologi Perjanjian Baru, pen., Lisda Tirtapraja Gunandhi (Jakarta: BPK Gunung Mulia, 2000), hlm. 31. 
kehadiran-Nya di dunia ini bukan karena hasil hubungan suami isteri tetapi oleh Koh Kudus dan bahkan kehadiran-Nya telah dinubuatkan berabad-abad tahun sebelum kehadiran-Nya oleh para nabi.

Di dalam Perjanjian Baru, gagasan Yesus sebagai Allah adalah hal yang sangat penting disebabkan karena hal ini menunjukkan bahwa la (Yesus) bukan sekedar nabi, imam atau Yesus hanyalah seoarang biasa yang dipilih oleh Allah untuk melakukan tugas dan kehendak-Nya dan yang diberi kuasa sebagaimana pandangan aliran-aliran yang bertentangan dengan iman Kristen. Dalam Tradisi Kristen Yahudi, gagasan-gagasan yang mengarah kepada pengakuan terhadap Yesus sebagai Allah sebenarnya sangat menonjol sepcrti gagasan anak manusia. gagasan Mesias, hamba Allah bahkan gagasan Anak Allah. Kesemuaan gagasan itu sangat erat hubungannya dengan karya dan sifat-sifat keilahiaa-Nya.

Berhubungan dengan karya-Nya, bahwa hanya Allah saja yang dapat melakukan perbuatan-perbuatan ajaib yang bersifat permanen dan hanya Allah sajalah yang dapat mengampuni, menyucikan dan membebaskan nianusia dari hukuman dosa. Berhubungan dengan sifatsifat ilahi Yesus, hanya Allah sajalah yang Mahatahu, Mahakuasa, Mahapengampun juga Mahahadir. Dengan memperhatikan perbuatan dan sifat-sifat ilahi dari Yesus. maka sangat diyakini bahwa Kristus adalah Allah sendiri, dengan demikian genaplah apa yang dicatat oleh Firman Tuhan berikut ini: Lalu terdengarlah suara dari Sorga yang mengatakan: "Inilah Anak-Ku yang Kukasihi, kepada-Nyalah Aku berkenan ' Firman itu telah menjadi manusia dan diam diantara kita, dan kita telah melihat kemuliaan-Nya yaitu kemuliaan yang diberikan kepada-Nya sebagai Anak Tunggal Bapa, penuh kasih karunia dan kebenaran.

\section{d. Allah Roh Kudus}

Berbicara tentang Roh Kudus, seringkali orang mempunyai pandangan yang keliru dan sempit. Roh Kudus seringkali dipahami hanya sebatas kuasa atau kekuatan supranatural yang dikeluarkan oleh Allah. Pengertian dasar yang perlu dibangun sebelum kita menyatakan bahwa Roh Kudus adalah Allah, yaitu kita perlu tahu bahwa Roh Kudus adalah satu pribadi. Pengertian sederhana dalam memahami pribadi Roh Kudus adalah dengan kita memahami pengertian Allah 
adalah Roh. Karena Roh itu Roh Allah, maka jelas bahwa semua sifat dan karateristik Roh Kudus adalah sifat dan karakteristik dari Allah. Roh Kudus adalah pribadi yang dijanjikan oleh Yesus kepada muridmurid-Nya yang mempunyai sifat-sifat ilahi, Mahatahu. Mahakudus. Mahahadir, Mahakuasa yang secara aktif dan bersama-sama dengan pribadi-pribadi yang lainnya berkarya dalam proses penciptaan dunia. penciptaan manusia. proses kelahiran Ycsus, proses penyelamatan manusia serta proses penghakiman pada akhir zaman nanti.

Akhirnya marilah kita berpikir dengan baik yang diterangi oleh Roh Kudus tentang Allah yang mengarahkan kita kepada pengakuan yang tulus bahwa Allah Tritunggal adalah Allah satu-satunya yang layak dipuji dan disembah sebagaimana Firman Tuhan "dan segala lidah mengaku: Yesus Kristus adalah Tuhan, bagi kemuliaan Allah, Bapa.

\section{KUALITAS KARYA ALLAH TRITUNGGAL}

Banyak ayat-ayat dalam Alkitab yang membahas dan memberitahukan tentang karya Allah Tritunggal dalam menyelamatkan manusia, untuk memberikan penjelasan yang berhubungan dengan kualitas karya Allah Tritunggal kita Efesus adalah rujukan yang dianggap paling tepat secara khusus pada pasal 1:3-14.

\section{Karya Allah Bapa}

Untuk dapat memahami dan mengerti akan ketakterbatasan karya Allah, maka perlu untuk dibuktikan dengan suatu studi terhadap katakata yang dipandang penting yang berhubungan dengan karya Allah Bapa. Eksegesis Ayat 4 dan 5 "Sebab di dalam Dia, Allah telah memilih kita sebelum dunia dijadikan, supaya kita kudus dan tak bercacat di hadapan-Nya." (Bahasa Yunani transletrasi) katos exelexato enias en auto pro katabole's kosmou einaiemasagios kai amomuos kate'nopion auto en agape." 


\section{a. Makna Kata $\varepsilon \dot{\xi} \varepsilon \lambda \xi \alpha \tau 0$}

Kata exelesato adalah kata kerja yang berasal dari kata eklegomai yang artinya memilih. ${ }^{11}$ Dengan kala waktu aoris dan diatesisnya dalam bentuk middle serta mempunyai modus indikatif dengan jumlah tunggal. Kata exelesato diterjemahkan Ia telah memilih. Kata ini menurut Fritz Reinker berasal dari kata $\alpha \kappa \lambda \varepsilon \dot{\varepsilon} \gamma \omega$ yang terjemahannya to choose, ${ }^{12}$ yang meliputi tiga ide pokok. Pertama, akar kata dari kata ini menunjukkan pemberitaan berakhir. Kedua, kata depan dalam penggabungan kata ini menunjukkan penolakan sesuatu dan penerimaan kepada yang lain. Ketiga; Suara menunjukkan FirmanNya. ${ }^{13}$

Dari ketiga makna di atas dijelaskan bahwa Allah yang melakukan pekerjaan dalam menerima dan menolak sebagian orang itu telah selesai dilaksanakan. Kata kerja ekxelesato, sebelumnya diawali dengan kata kathos yang diterjemahkan "Just as. because" yang menjelaskan hubungan sebab akibat dimana Allah yang telah mengaruniakan segala berkat rohani atau dapat dikatakan bahwa hanya oleh sifat-sifat Allah yang menyebabkan Dia memilih dan menolak sebagian orang. Selanjutnya kata exelesato, menerangkan bahwa proses pemilihan Allah itu terjadi di dalam Yesus yang artinya bahwa ia memilih untuk diri-Nya sendiri. Berhubungan dengan pemilihan Allah, memang menjadi suatu yang masih terus diperdebatkan hingga kini.

Pemilihan Allah atau yang dalam istilah teologi dikenal dengan predestinasi memang tidak terdapat dalam Perajanjian Lama. Istilah ini sendiri berasal dari bahasa Latin "Prodestinate" yang dalam bahasa Yunani "prooridso" yang artinya menandai sebelumnya. ${ }^{14}$ Predestinasi memiliki dua aspek yaitu aspek luas, dimana Allah menetapkan sebelumnya apa yang akan terjadi (peristiwa-peristiwa dan sejarah) dan aspek sempit, dimana sejak kekekalan Allah telah memilih sebagian orang untuk diselamatkan dan sisanya berajalan menurut kehendaknya.

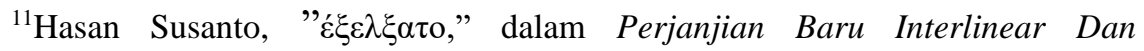
Konkordansi Yunani - Indonesia (Jakarta: Lembaga Alkitab Indonesia, 2004), hlm. 2:261.

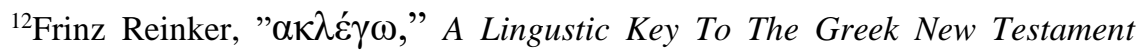
(Grand Rapids: Zondervan Publishing House, 1980), hlm. 521.

${ }^{13}$ Ibid.

${ }^{14}$ Paul Enns, "Predistinasi," The Moody HandBook Of Theology (Malang: Literatur SAAT, 2004), hlm. 2:111.
} 
Untuk mengetahui pandangan-pandangan yang berbeda tentang pemilihan Allah. Beberapa pandangan dari para teolog tentang konsep Predestinasi. Konsep predestinasi menurut Calvin: "Allah tanpa syarat dari sejak kekekalan telah memilih sebagian orang untuk diselamatkan. ${ }^{15}$ Pemilihan Allan tidak berdasarkan pada respon manusia di masa yang akan datang. Predestinasi dalam pandangan Calvin dijabarkan dalam lima pokok penting yang sangat hakiki yaitu pertama; Total Anability (kerusakan Total) Seluruh manusia telah hilang dan jatuh dalam dosa dan mengakibatkan kerusakan total. Kenyataan ini yang menyebakan manusia tidak mampu memberi tanggapan terhadap anugerah Allah dan memenuhi satu syarat pun untuk menerima keselamatan. Kedua; Unconditional Election (pemilihan tanpa syarat), pernyataan ini menunjukkan kedaulatan Allah yang telah menciptakan segala sesuatu dan Dia yang bebas berbuat apa saja yang dikehendaki-Nya. Ketiga; Limited Atonement (penebusan terbatas) Pernyataan ini menjelaskan bahwa dari sejak kekekalan Allah mempunyai rencana untuk menyelamatkan sebagian umat dan menolak yang lain dan hal ini tidak ada sangkut pautnya dengan keadilan Allah. Efficucious Grace (Anugerah yang tidak dapat ditolak) Panggilan yang elektif ini adalah anugerah Tuhan yang bebas dan khusus bukan dari apapun yang dilihat dalam diri manusia. Kondisi manusia secara keseluruhan pasif, hanya oleh Roh Kuduslah yang mengaktifkan dan memperbaikinya. Pernyalaan ini menegaskan bahwa tak ada seorangpun yang dipanggil dalam anugerah Allah akan menjadi murtad atau berbalik dari Allah, tetapi mereka akan bertekun sampai pada akhirnya. ${ }^{16}$

Dari keempat hal di atas, dapat disimpulkan sesuai dengan Roma 3:23, "Karena semua orang telah berbuat dosa dan telah kehilangan kemuliaan Allah." Dan oleh karena itu manusia patut dihukum. Namun Allah juga mengetahui akan siapa yang akan bertobat sehingga terhitung dalam pemilihan Allah sebelum dunia dijadikan, dan pemilihan itu hanya berdasarkan anugerah Allah.

Konsep predestinasi menurut pandangan Ariminiamisme dijadikan: Allah memilih mereka yang Ia tahu akan percaya berdasarkan kehendak bebas mereka. Pilih Allah bersyarat, berdasarkan

\footnotetext{
${ }^{15}$ Enns, "Predistinasi," The Moody HandBook Of Theology, hlm. 1:123.

${ }^{16}$ Gilbert Lumoindong, Dipilih Sebelum Dunia Dijadikan (Yogyakarta: Yayasan Andi, 2004), hlm. 19-25.
} 
respon manusia dan iman. ${ }^{17}$ Penekanan pandangan Armineus bahwa manusia masih memiliki kehendak bebas sekalipun manusia telah jatuh dalam dosa. Kehendak bebas inilah yang membuatnya dapat atau tidak meresponi anugerah Allah. Jadi usaha manusia dalam merespon adalah salah satu faktor pcnyebab anugerah Allah dinikmati. Hak ini berarti bahwa Allah dan manusia bekerjasama dalam proses penyelamatan manusia.

Predestinasi menurut Luther: "Keselamatan berdasarkan Rahmat Allah, yang dalam belas kasihan-Nya mengangkat orang berdosa menjadi atau sebagai anak-Nya, berdasarkan ketidakmampuan manusia dan kerusakan total ${ }^{18}$ Martin Luther menekankan bahwa manusia telah rusak baik secara jasmani tetapi juga rohani dan diperlukan perbaikan, demikian juga dengan kelidakmampuannya harus ada yang membantu mereka untuk memiliki kemampuan. Jika ditelusuri lebih jauh, kata pilihan mempunyai makna yang sangat luas dan oleh J. I. Packer penggunaannya dikategorikan dalam dua bagian masa yakni masa Perjanjian Lama dan Perjanjian Baru. ${ }^{19}$

Pemakaian dalam Perjanjian Lama, kata utama yang digunakan untuk menyatakan gagasan pilihan Allah adalah בַכֵַ "bakar" yang berarti memilih seseorang atau sesuatu dengan seksama sesudah menimbang dengan masak-masak kemungkinan-kemungkinan lain. Kata ini mencakup pilihan sangat menyukai halyang dipilih. Harun Hadiwiyono menjelaskan bahwa "di dalam Perjanjian Lama kata memilih mempunyai arti yang bermacam-macam jika kata ini diterapkan pada Allah dalam sikapnya terhadap manusia dan itu sangat erat hubungannya dengan kata kasih atau mengasihi. ${ }^{20}$ Pada zaman Perjanjian Lama, bangsa Israel adalah gambaran tindakan pemilihan Allah dari penggunaan kataרַּ (bakar).

Lebih lanjut dijelaskan oleh J. I. Packer bahwa, pemilihan Allah atas Israel dilaksanakan dengan dua tindakan yang saling berkaitan, yang pertama adalah Allah memilih Abraham dan keturunannya dengan jalan memanggil Abraham keluar dari Ur dilanjutkan dengan perjanjian kekal dan yang kcdua adalah Allah memilih keturunan

${ }^{17}$ Enns, "Predistinasi," The Moody HandBook Of Theology, hlm. 2:123.

${ }^{18}$ W. J. Kooman, Martin Luther (Jakarta: BPK Gunung Mulia, 1985), hlm. 154.

${ }^{19}$ J. I Packer, "Pilihan," dalam Ensiklopedi Alkitab Masa Kini, pen., M. H. Simanungkalit (Jakarta: Yayasan Komunikasi Bina Kasi/OMF, 2004), hlm. 2:266.

${ }^{20}$ Harun Hadiwiyono, Pilihan Kasih Karunia, Iman Kristen (Jakarta: BPK Gunung Mulia, 2005), hlm. 293. 
Abraham dengan melepaskan mereka dari perbudakan dan perhambaan di Mesir dan memperabaharui perjanjian kepada Abraham dalam bentuk yang lebih luas di gunung Sinai. ${ }^{21}$

Pemakaian dalam Perjanjian Baru, kata yang digunakan sebagai gagasan pemilihan Allah terhadap seseorang atau sesuatu sebagaimana

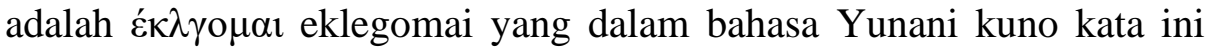
biasanya dipakai dengan arti aktif, tetapi para penulis Alkitab selalu memakainya dalam bentuk yang berarti memilih untuk diri sendiri. ${ }^{22}$ Jika dalam Perjanjian Lama pemilihan Allah hanya kepada orang Yahudi atau keturunan Abraham secara lahiriah, namun dalam Perjanjian Baru perjanjian itu telah diperluas kepada orang-orang yang menjadi keturunan Abraham melalui iman kepada Yesus Kristus, sebagaimana yang dikatakan oleh R. Soedarmo bahwa: "Kedatangan Yesus Kristus pada kegenapan masa hidup-Nya, penderitaan-Nya, kematian dan kebangkitan-Nya serta kenaikan-Nya adalah pusat mendasar dari perjanjian anugerah. ${ }^{23}$

Untuk hal ini lebih jauh J. I. Packer menjelaskan bahwa Perjanjian Baru menggunakan tiga gagasan tentang pemilihan yakni pertama, bahwa Yesus dinyatakan sebagai yang dipilih. ${ }^{24}$ Kedua, bahwa ungkapan yang dipilih berarti persekutuan orang-orang Kristen dalam sifatnya sebagai umat pilihan Allah. ${ }^{25}$ Ketiga, bahwa pemakaian kata eklegomai ditujukan untuk pelayanan-pelayanan khusus. Dalam perkembangan teologi dimasa Perjanjian Baru, ide pemilihan secara teologis dan lengkap terdapat dalam surat-surat Paulus (Rm. 8:28-9:36; Ef. 1:3-14; 1 Tes. 1:2-10; 2 Tes. 2:13-14 dan 2 Tim. 2:9-10) yang tercakup dalam empat pokok pikiran, yaitu pemilihan berdasarkan kasih karunia, pemilihan berdasarkan kedaulatan Allah, pemilihan terjadi dalan kekekalan dan pemilihan di dalam dan melalui Yesus Kristus.

Dengan memperhatikan berbagai penjelasan di atas, maka dapat dikatakan bahwa proses keselamatan itu terjadi sebagai berikut: Pertama, keselamatan telah disediakan bagi manusia sejak kekekalan masa lampau dalam keputusan Allah Tritunggal. Kedua, pemilihan dan

${ }^{21}$ Packer, "Pilihan," dalam Ensiklopedi Alkitab Masa Kini, 2:267.

${ }^{22}$ Ibid., hlm. 267.

${ }^{23}$ R. Soedarmo, Perjanjian Anugerah, Iktisar Dogmatika (Jakarta: BPK Gunung Mulia, 2001), hlm. 167.

${ }^{24}$ Packer, "Pilihan," dalam Ensiklopedi Alkitab Masa Kini, hlm. 2:268.

${ }^{25}$ Ibid. 
penolakan sebagian orang dalam menanggapi kasih karunia Allah dilakukan oleh Allah Tritunggal sejak kekekalan masa lampau didasari oleh sifat-sifat dan kesempurnaan Allah. Kctiga, keselamatan dikerjakan di dalam dan melalui Yesus lewat kematian dan kebangkitan-Nya. Kitab Efesus 1:5 memberikan pernyataan yang kuat bahwa "Dalam kasih la telah menentukan kita dari semula oleh Yesus Kristus untuk menjadi anak-anak-Nya sesuai dengan kerelaan kehendak-Nya.

\section{b. Makna Kata Пpoopıбáৎ (Proorisas)}

Проopıбós (Proorisas) adalah kata kerja yang berasal dari akar

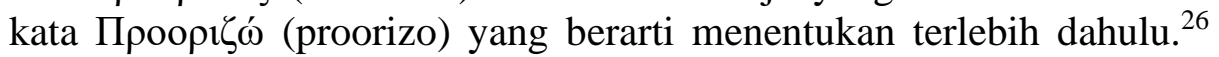

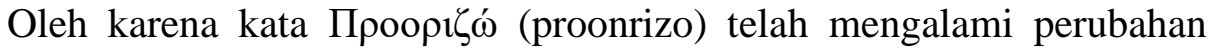
dimana kata ini sebagaimana dalam teks diakhiri dengan akhiran kata kerja aoris orang kedua tunggal $\alpha \varsigma$ (as) dan juga penggunaan kata depan Про (pro), yang menunjukkan kasus ablative (pemisahan) yang artinya adalah sebelum. Dengan demikian, secara keseluruhan kata Проopıбós

(proorisas) diterjemahkan "engkau telah ditentukan dan dipisahkan sebelumnya" Fritz Reinker menjelaskan bahwa kata Проoрıбós (Proorisas) berbentuk aoris aktif partisip, yang berasal dari kata

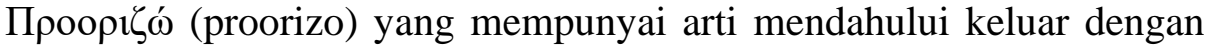
sebuah batas juga untuk menyatakan takdir, sedang kata depan Про adalah sebab yang memberikan alasan bagi pemilihan. ${ }^{27}$ Dengan

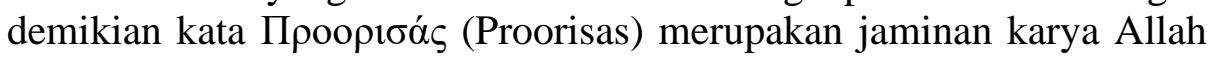
bahwa seorang yang dipilih sebelum dunia dijadikan adalah yang telah ditentukan dari semula.

\section{Karya Allah Anak "Yesus Kristus"}

Sebagaimana karya Allah Bapa yang telah dijelaskan di atas dengan memperhatikan kata-kata penting yang berhubungan dengan

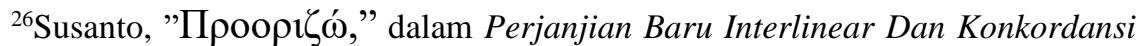
Yunani-Indonesia, hlm. 2:673.

${ }^{27}$ Reinker, "Проорıбás," A Lingustic Key To The Greek New Testement, hlm. 521-522.
} 
karya Bapa, demikian pula untuk memahami dan mengerti akan ketakterbatasan karya Yesus Kristus, maka harus diselidiki pula beberapa kata penting yang berhubungan dengan karya Yesus sebagai pribadi kedua dalam Allah Tritunggal. Ada beberapa kata penting dalam kitab Efesus 1:7-11 yang perlu dipahami yang menegaskan Pekerjaan Yesus Kristus.

\section{a. Makna Kata $\alpha \pi 0 \lambda v \tau \rho \omega \sigma \mathrm{vv}$ (apolutrosin)}

Kata $\alpha \pi \circ \lambda v \tau \rho \omega \sigma \mathrm{lv}$ (apolutrosin) adalah kata benda dari akar kata $\lambda v \tau \rho o \omega$ yang artinya membebaskan. ${ }^{28}$ Dalam teks kata $\lambda v \tau \rho \circ \omega$ diawali dengan kata depan $\alpha \pi$ o yang berarti dari, jauh dari, yang menyatakan pemisahan dan berakhiran orang ketiga tunggal dalam bentuk feminim, dengan bentuk kasusnya adalah akusatif, sehingga secara keseluruhan diterjemahkan "penebusan."

Fritz Reinker menjelaskan bahwa kata $\alpha \pi \mathrm{\alpha} \lambda v \tau \rho \omega \sigma 1 \varsigma$ (apolutrosis) adalah kata yang menandakan kebenaran dan hasil penjumlahan serta perwujudan dari perbuatan dosa. Kata ini mempunyai arti pembelian dengan sebuah harga penebusan atau penyelamatan yang memiliki kesejajaran dengan kata $\alpha \phi \varepsilon \sigma \iota \varsigma$ yang berarti pembebasan, pelepasan, memaafkan. ${ }^{29}$

Dua kata penting yang berhubungan dengan penebusan dalam bahasa Yunani yang berkaitan satu dengan yang lain, sebagaimana yang dijelaskan oleh W. E. Vine. Merril F. Ungen, dan William White adalah: pertama; $\varepsilon$ $\xi \gamma o \rho \alpha \zeta \omega$ (exagorazo) berasal dari bentuk atau kata ayopaw yang mempunyai arti membeli dalam pengertian membayar dan membawa keluar, sedang kata depan $\varepsilon \dot{\xi}$ yang berasal dari kata $\varepsilon \kappa$ yang berarti khusus untuk pembelian seorang budak dengan maksud membebaskannya. Kata ini digunakan sebagai gambaran bagi kebebasan yang diberikan oleh Kristus kepada orang Kristen dari hukuman dan kutukan juga digunakan untuk kepentingan diri sendiri (kepentingan si pembeli). Pembelian ini adalah kesempatan yang tepat

\footnotetext{
${ }^{28}$ Susanto, " $\lambda v \tau \rho o \omega, "$ dalam Perjanjian Baru Interlinear Dan Konkordansi Yunani - Indonesia, hlm. 2:496.

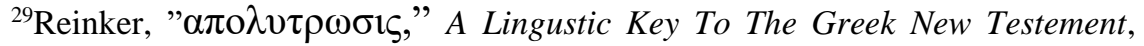
hlm. 522.
} 
dan merupakan waktunya Tuhan. ${ }^{30}$ Kedua; $\lambda v \tau \rho o \omega$ lutro yang artinya membebaskan dalam bentuk tebusan. Ini digunakan bagi kepentingan diri sendiri berarti membenarkan dalam pengertian untuk membebaskan dengan pembelian atau pembayaran sebuah harga tebusan untuk membebaskan dalam pengertian biasa dari membebasakan. Di dalam pengertian rohani ditujukan kepada pekerjaan Kristus dalam membebaskan manusia dari semua kesalahan dan hukuman dengan diri-Nya sendiri menjadi tebusan. ${ }^{31}$

Bertolak dari penjelasan-penjelasan di atas, dapat disimpulkan bahwa penebusan dilakukan tidak didasarkan pada perbuatan orang yang ditebus, tetapi oleh kehendak dan kemauan Allah sendiri untuk menebus. Sehubungan dengan proses penebusan itu sendiri, di dalam

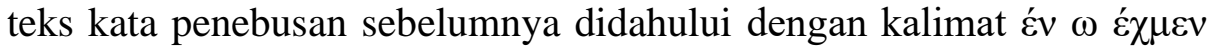
menerangkan bahwa penebusan itu terjadi di dalam dan melalui Kristus.

Jika diperhatikan dari penggunaan kata-kata dalam konteks aslinya, maka penebusan itu menjadi suatu yang khusus bagi mereka yang menurut kehendak yang mau menebus mereka, sehingga penebusan itu tidak berlaku bagi semua orang. Berikut ini pandangan mengenai konsep penebusan. Konsep penebusan Terbatas, hampir semua teolog reformis berpendapat bahwa Kristus mati sebagai kematian substitusionari bagi semua orang. Calvin berpendapat bahwa penebusan sifatnya terbatas dan tidak dapat dinikmati oleh semua orang, sebab orang-orang tertentu harus diselamatkan sebagai akibat dari pemilihan Allah yang tak bersyarat dan bahwa semua orang yang telah dipilih Allah dan Kristus telah mati untuk mereka, akan diselamatkan.

Penebusan yang dilakukan di dalam dan melalui Yesus Kristus tentunya mempunyai maksud dan tujuan bagi manusia yang terlihat pada makna kata-kata berikut:

Pertama, makna kata ó $\phi \varepsilon \sigma ı v$ (a'phesin) yang adalah kata benda dari akar kata ó $\phi \varepsilon \sigma ı \varsigma$ (a'phesis) yang artinya penebusan atau pengampunan.

Kata ó $\phi \varepsilon \sigma v v$ (a'phesin) adalah kata benda feminim orang ketiga tunggal dengan kasus akusatif yang menyatakan bahwa akibat dari

\footnotetext{
${ }^{30}$ W. E. Vine, Merril F. Ungen, William White, "Redeem," Complete Expocitory Dictionary Old and New Testament Word (Canada: Thomas Nelson Publisher, 1985), hlm. 515 .

${ }^{31}$ Ibid.
} 
penebusan itu adalah pengampunan. Jadi dapat dikatakan bahwa la yang menebus dosa, la juga yang mengampuni. Sebagaimana jaminan yang diberikan oleh Bapa kepada mereka yang dipilih, maka jaminan yang diberikan oleh Allah Anak (Yesus Kristus) kepada mereka yang ditebus dan diampuni dosa dan pelanggarannya adalah mendapat bagian yang dijanjikan. Kata yang dipakai dalam konteks asli adalah $\varepsilon \kappa \lambda \eta \rho \omega \theta \eta \mu \varepsilon v$ (eklerothemen) yang berasal dari akar kata $\kappa \lambda \eta \rho \omega$ (klero) yang berarti memilih atau menentukan menjadi bagiannya atau mendapat bagiannya. ${ }^{32}$ Dalam konteks kata $\kappa \lambda \eta \rho \omega$ diawali dengan kata ganti orang pertama tunggal yang berarti aku yang fungsinya adalah sebagai subyek kalimat dan diakhiri dengan akhiran orang pertama jamak yang fungsinya sebagai obyek kalimat. Dengan demikian dapat diterjemahkan "kita dipilih oleh-Nya untuk menjadi bagian-Nya. Proses pemilihan ini telah terjadi dan peristiwa itu sungguh-sungguh terjadi.

Kedua, kata $\pi \rho 0 o \rho ı \theta \varepsilon v \tau \varepsilon \varsigma$ (prooristhentes) adalah kata kerja yang berasal dari akar kata "horisohohorizo" yang berarti menetapkan," yang kemudian dalam penulisannya kata ini diawali dengan kala depan $\pi \rho 0$ (pro) yang berarti sebelum, yang nenunjukkan kepada kasus ablatif, sehingga diterjemahkan "ditentukan terlebih dahulu."33

Jadi jika kita memperhatikan penjelasan-penjelasan kedua kata di atas, dapat disimpulkan bahwa kita telah dipilih untnk mendapat bagian-Nya oleh karena telah ditentukan lebih dahulu. Bagian seperti apa yang dicatat dalam teks, adalah apa yang dicatat dalam ayat 7-10 bahwa janji itu adalah penebusan dan janji mempersatukan kita dengan Kristus. William Barclay menjelaskan bahwa bagian ini bahwa Rasul Paulus sedang menyatakan bangsa Yahudi yaitu dengan penggunaan kata "kami harus percaya kepada kedatangan Mesias yang dijanjikan, namun disisi lain Ia juga menyatakan bahwa berkat yang dijanjikan itu adalah tanah dan kewarganegaraan. ${ }^{34}$ Secara rohani setiap orang yang diadopsi menjadi anak-anak Allah akan mendapat tempat dan kewarganegaraan kita sebagai ahli waris. Jadi jelas bahwa karya Allah Anak (Yesus Kristus) juga mempunyai dan memberikan jaminan bagi mereka yang telah dipilih dan ditentukan serta ditebus untuk apa yang

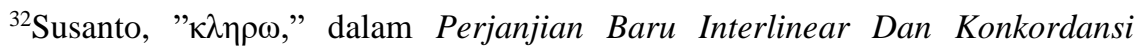
Yunani-Indonesia, hlm. 2:452.

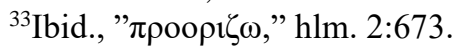

${ }^{34}$ William Barclay, Pemahaman Alkitab Setiap Hari, Galatia-Efesus, pen., S. Wismoady (Jakarta: BPK Gunung Mulia, 1996), hlm. 127.
} 
juga telah disediakan bagi mereka, yaitu penebusan dan menjadi umatNya dalam satu persekutuan dengan Kristus. Selanjutnya agar lebih menyakinkan kita tentang karya Allah Tritunggal maka kita akan melihat juga apa yang dikerjakan oleh pribadi Roh Kudus.

\section{b. Karya Allah Roh Kudus}

Oleh karena scgala peristiwa dan kejadian yang terjadi baik masa lampau maupun masa kini sangat erat hubungannya dengan Tritunggal Allah, maka tidak cukup kalau kita hanya membahas karya dari dua pribadi yang lain dan tidak membahas satu pribai yang lain. Hal ini disebabkan karena keterkaitan pribadi-pribadi itu sendiri dan juga adanya keterkaitan dari karya-karya masing-masing pribadi. Jika diperhatikan dalam teks Firman Tuhan, secara kliusus pada ayat 13-14, sangat jelas terlihat dan terbaca oleh kita apa yang menjadi karya dari Roh Kudus, yaitu Roh Kudus memeteraikan kita yang percaya menjadi anak-anak Allah dan Roh Kudus juga menjadi jaminan bagi kita yang percaya untuk mendapat seluruh bagian yang dijanjikan. Ayat 13-14 "Di dalam Dia kamu juga - karena kamu telah mendengar Firman kebenaran, yaitu Injil keselamatanmu - di dalam Dia kamu juga ketika kamu percaya dimeteraikan dengan Roh Kudus yang dijanjikan -Nya itu.

\section{c. Kata $\varepsilon \sigma \phi \rho \alpha \gamma\llcorner\sigma \theta \eta \tau \varepsilon$ (esphragisthete)}

Kata $\varepsilon \sigma \phi \rho \alpha \gamma i \sigma \theta \eta \tau \varepsilon$ (esphragisthete) adalah kata kerja yang berasal dari akar kata $\sigma \phi \rho \alpha \gamma i \zeta \omega$ (sphragizo) yang pengertiannya adalah menyegel, menandai dengan segel dan mengakui. ${ }^{35}$ Dalam teks, kata $\sigma \phi \rho \alpha \gamma i \zeta \omega$ (sphragizo) diawali dengan $\dot{\varepsilon}$ yaitu kata orang yang menunjukkan kepada orang pertama tunggal yang berarti saya, aku, yang fungsinya sebagai subyek dan diakhiri dengan akhiran orang kedua jamak dengan bentuk waktu aoris, sehingga kata $\varepsilon \sigma \phi \rho \alpha \gamma i \sigma \theta \eta \tau \varepsilon$ (esphragisthete) diterjemahkan aku telah menandai kamu. Memahami pikiran dan pandangan Rasul Paulus tentang kata $\varepsilon \sigma \phi \rho \alpha \gamma 1 \sigma \theta \eta \tau \varepsilon$ (esphragisthete), maka perlu melihat penggunaan kata meterai baik

\footnotetext{
${ }^{35}$ Susanto, " $\sigma \phi \rho \gamma i \zeta \omega, "$ dalam Perjanjian Baru Interlinear Dan Konkordansi Yunani-Indonesia, hlm. 2:739.
} 
pada zaman Perjanjian Lama dan juga pada zaman Perjanjian Baru. Zaman Perjanjian Lama, penggunaan meterai sebenarnya telah ada sejak jaman purba dalam bentuk meterai pahatan.

Orang Ibrani menggunakan istilah umum yang tidak merincikan bentuk dari meterai itu dengan istilah "khotam." 36 Tujuan penggunaan meterai pada masa PL adalah untuk menyatakan keaslian, jaminan, juga untuk menyatakan kesahaan atau secara lisan meterai melambangkan suatu yang dipegang teguh. Sedangkan pada meterai digunakan sebagai untuk memberikan jaminan kejujuran (Rm. 15:28), menjelaskan pengesahan (1 Kor. 9:2) dan juga sebagai jaminan perlindungan (Why. $7: 2-8 ; 9: 4)$.

Ada tiga petunjuk yang sama diberitahukan dalam Efesus 1:13, yakni dalam arti kiasan dimeteraikan sebagai orang-orang percaya oleh Roh Kudus, menjadi milik dan satu gagasan tempat yang dituju dari penekanan kalimat Roh Kudus yang dijanjikan. Kata lain yang perlu diperahatikan dengan baik adalah kata jaminan dalam ayat 14 sebagai berikut: "Dan Roh Kudus Allah itu adalah jaminan bagian kita sampai kita memperoleh seluruhnya, yaitu penebusan yang menjadikan kila milik Allah, untuk memuji kemulian-Nya.

\section{d. Kata $\alpha \rho \rho \alpha \beta \omega ́ v($ arrabon)}

Kata $\alpha \rho \rho \alpha \beta \omega ́ v$ (arrabon) adalah kata benda bentuk maskulin tunggal dengan kasus nominatif, yang mempunyai pengertian panjar atau jaminan. ${ }^{37}$ Oleh karena bentuk kasus kata ini nominatif yang menunjukkan pada subyek kalimat, yang dalam teks asli dinyatakan dengan penggunaan kata ó yang adalah kata ganti relatif dalam bentuk netral tunggal dengan kasus nominatif yang berarti siapa. ia, dia. Bentuk netral dalam teks memberi petunjuk bahwa subyek kalimat bukan benda ataupun manusia, sehingga jika dicermati dengan baik ayat 13-14, maka subyek kalimatnya lebih terarah atau tertuju pada Roh Kudus.

Apabila kita kaitkan subyek kalimat ini dengan kata $\varepsilon \sigma \tau \imath v$ (estin) yang mengikutinya yang adalah kata kerja orang ketiga tunggal kini

${ }^{36}$ D. J. Wisman, A. R. Millard, "Meterai," dalam Ensiklopedi Alkitab Masa Kini, pen., Soetarno (Jakarta: Yayasan Komunikasi Bina Kasih/OMF, 2004), hlm. 76.

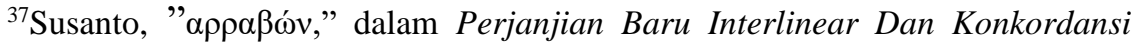
Yunani-Indonesia, hlm. 2:115. 
aktif indikatif, yang berasal dari kata cí $\mu$ í yang artinya ada, adalah. menjadi, ${ }^{38}$ maka terjemahannya adalah Roh Kudus menjadi jaminan untuk menerima bagian yang telah ditentukan. Fritz Reinker menjelaskan bahwa kata $\alpha \rho \rho \alpha \beta \omega ́ v$ (arrabon) yang artinya panjar, jaminan, menunjukkan sebuah milik yang tersimpan, dimana ada di dalam dirinya adalah sebuah jaminan bahwa seluruhnya akan dibayarkan. Panjar atau jaminan adalah sama dengan pembayaran penuh. Jadi karya Roh Kudus adalah tidak hanya menjadikan setiap orang yang percaya menjadi kudus, tetapi juga menjadi jaminan untuk menerima warisan yang telah dijanjikan bagi mereka yang percaya.

\section{Kesetaraan Kualitas Karya Allah Tritunggal}

Sudah dapat kita ketahui karya Allah Tritunggal bahwa Allah Bapa memilih dan menentukan dari semula, sebelum dunia dunia dijadikan, sebagian orang untuk diselamatkan dan sebagian lagi tidak. Allah Anak (Yesus Kristus) yang menebus mereka yang dipilih dan ditentukan dan oleh mereka mendapat pengampunan dosa dan Allah Roh Kudus yang memeteraikan mereka yang dipilih. ditentukan, ditebus dan diampuni dosanya menjadi anak-anak Allah dan juga menjadi jaminan bagi mereka untuk menerima warisan yang telah dijanjikan. Keseluruhan tindakan dan perbuatan Allah dalam menyelamatkan manusia yang diperlihatkan dalam kitab Efesus 1:3-14 didasari oleh sikap hati Allah yang penuh dengan belas kasihan yang dalam ungkapan Yohanes "begitu besar kasih" yang sesungguhnya adalah ukuran dari kualitas karya ketiga pribadi.

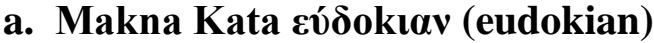

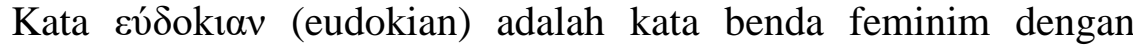
jumlah tunggal dan bentuk kasusnya akusatif, berasal dari akar kata

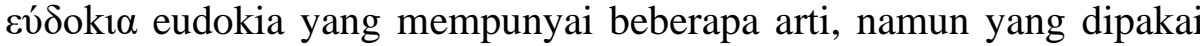
di dalam teks asli adalah "maksud baik." Kata ini dipakai dua kali yaitu dalam ayat 5 dan ayat 9. Yang selanjutnya oleli lembaga Alkitab Indonesia diterjemahkan "kerelaan." Kata "kerelaan" di dalam Kamus

\footnotetext{
${ }^{38}$ Susanto, "Eí $\mu$ í," dalam Perjanjian Baru Interlinear Dan Konkordansi Yunani - Indonesia, hlm. 2:244.
} 
Besar Bahasa Indonesia mempunyai arti kesediaan atau perkenan. Jika disimak dari arti literalnya, kata ini menunjukkan kepada suatu sikap hati. Jadi apabila dihubungkan dengan teks Firman Tuhan, ini berarti bahwa semua yang dilakukan oleh Allah didasari oleh karena hati-Nya berbelas kasihan kepada manusia. Belas kasihan Allah tidak dipengaruhi oleli sikap hidup manusia itu dengan perbuatan-perbuatan baik, tetapi oleh karena Allah sendiri yang berinisiatif untuk mengasihi manusia. Wujud kasih Allah itu adalah dengan memilih sebagian orang untuk diselamatkan dengan jalan penebusan oleh kematian Yesus Kristus dan dijamin Roh Kudus sebagai anak-anak Allah.

Sekalipun kata eudokian pemakaiannya hanya muncul dalam karya Allah Bapa dan juga Yesus Kristus, tetapi kata ini juga berlaku bagi karya Roh Kudus dengan maksud yang tersirat. sebab jika Allah Bapa dalam kerelaan kehendak-Nya memilih dan menentukan, Yesus Kristus dalam kerelaan kehendak-Nya menebus dan mengampuni, maka jelas bahwa Roh Kudus yang adalah Allah dalam kerelaan kehendak-Nya memeteraikan dan menjamin status orang-orang pilihan dan tebusan sebagai warga kerajaan Allah. Kerelaan ketiga pribadi ini tidak sedang menjadikan pikiran kita salah terhadap Allah bahwa kehendak Allah Bapa berbeda dengan kehendak Allah Anak juga berbeda dengan Allah Rolh Kudus atau sebaliknya, namun kerelaan kehendak ketiga pribadi tersebut adalah Kerelaan kehendak Allah.

\section{b. Maka Kata $\delta o \xi \eta \varsigma$ doxes}

Kata $\delta$ o $\xi \eta \varsigma$ (doxes) adalah kata benda bentuk feminim dengan jumlah tunggal dalam kasus genetif yang berasal dari akar kata $\delta o \xi \alpha$ (do'xa) yang berarti kemuliaan, kebesaran, ketenaran dan pujian, ${ }^{39}$ namun arti yang tepat yang dipakai dalam teks asli adalah "kemuliaan." Penggunaan kata ini dalam teks muncul sebanyak tiga kali, baik berhubungan dengan karya Allah Bapa, Allah Anak (Yesus Kristus), juga karya Roh Kudus. Oleh karena penggunaannya yang berulangulang, maka kata ini tidak dapat diabaikan dari pengamatan kita karena menjadi sebuah kata yang penting.

\footnotetext{
${ }^{39}$ Susanto, "סo $\xi \alpha, "$ dalam Perjanjian Baru Interlinear Dan Konkordansi Yunani-Indonesia, hlm. 2:1026.
} 
Kata kemulian dalam Kamus Besar Bahasa Indonesia diartikan sebagai suatu keadaan, baik mulia keagungan juga kehormatan. Jika arti ini dikenakan pada kerelaan kehendak Allah, maka dapat diterjemahkan bahwa setiap karya Allah yang dilakukan sesuai dengan kerelaan-Nya, ditujukan hanya bagi kemuliaan. Kehormatan serta keagungan-Nya. Hal ini terlihat juga pada bentuk kasus yang ada pada kata do'xa dalam teks yang menunjukkan bahwa kemuliaan itu milik Allah.

Wycliffe, dalam bukunya menjelaskan bahwa penggunaan kata ini menandai peran yang dimiliki oleh masing-masing oknum ke-Allah-an di dalam keselamatan kita dengan memberi berkat yang telah sampai kepada kita. ${ }^{40}$ Kata kemuliaan dalam Perjanjian Lama umumnya diterjemahkan dengan kata Ibrani kavad yang menjadi ide "keakraban" dan dengan demikian mengacu kepada "bobot" atau nilai. Kata kemuliaan banyak dipakai dan jumpai bersamaan dengan umat Israel baik dalam perjalanan mereka di padang gurun yang dikenal dan nampak dalam tiang awan dan tiang api juga kemuliaan Tuhan di dalam kemah suci ketika bangsa Israel mengorbankan korban persembahan (Im. 9:6; 23). Dikemukakan oleh R. E. Nixon bahwa di dalam kitab Nabi-nabi terdapat dua konsep tentang kemuliaan Tuhan yakni konsep semi jasmani seperti nampak dalam penglihatan Yehezkiel yang dicatat dalam kitabYehezkiel 1:28 maupun yang lebih batiah seperti yang dicatat dalam kitab Yesaya 40:4-5; 6:1-3.

Dalam Alkitab Yunani Perjanjian Lama (Septuaginta) kata kavad diterjemahkan dengan kata Yunani doxa. Dalam bahasa Yunani sekuler doxa berarti pendapat atau reputasi. ${ }^{41}$ Jadi konsep terpenting dari semua bentuk kata dan penggunaannya adalah bahwa kemuliaan Tuhan menunjukkan pernyataan diri, sifat dan kehadiran Allah bagi manusia wujud jasmani (kehadiran Yesus Kristus dan dalam wujud Roh Kudus dalam diri orang percaya).

Jadi dengan memperhatikan penjelasan kedua kata tersebut di atas, maka penulis menyimpulkan bahwa "kesetaraan kualitas karya Allah Tritunggal adalah seluruh sifat dan kesempurnaan Allah yang

${ }^{40}$ Charles F. Pfeiffer, Everett F. Horrison, peny., Tafsiran Alkitab Wycliffe (Malang: Gandum Mas, 2001), hlm. 739.

${ }^{41}$ R. E. Nixon, H. A. Oppusunggu, peny, "Kemuliaan," dalam Ensiklopedi Alkitab Masa Kini, pen., J. M. Pattiasina (Jakarta: Yayasan Komunikasi Bina Kasih/OMF, 2004), hlm. 2:98. 
dikerjakan-Nya untuk diri-Nya sendiri, sesuai dengan kerelaan kehendak-Nya, bagi kemuliaan nama-Nya.

\section{DAFTAR PUSTAKA}

Alkitab. Jakarta: Lembaga Alkitab Indonesia, 2015.

Bakers, Theol. "Allah.” Pedoman Dokmatika. Jakarta: BPK Gunung Mulia, 2000.

Barclay, William. Pemahaman Alkitab Setiap Hari, Galatia-Efesus. Diterjemahkan oleh S. Wismoady. Jakarta: BPK Gunung Mulia, 1996.

Dankbaar, W. F. “Calvin.” Jalan Hidup Dan Karyanya. Jakarta: Badan Penerbit Kristen, 1976.

Davidson, Benjamain. "אלהֶים." Dalam The Analitycal Hebrew and Chaldee Lexicon. Michigan: Zondervan Publising House, 1980.

Enns, Paul. "Kata Pengantar." The Moody Handbook Of Theology. Malang: Literatur SAAT, 2004.

Guthrie, Donald. "Allah Sebagai Bapa." Teologi Perjanjian Baru. Diterjemahkan oleh Lisda Tirtapraja Gunandhi. Jakarta: BPK Gunung Mulia, 2000.

Hadiwiyono, Harun. Pilihan Kasih Karunia, Iman Kristen. Jakarta: BPK Gunung Mulia, 2005.

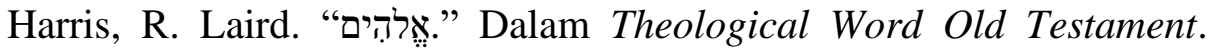
Chicago: Moody Press, 1980.

Hasugian, Johanes Waldes. "Kurikulum Dan Pembelajaran Warga Jemaat Dewasa Di Gereja." KURIOS (Jurnal Teologi dan Pendidikan Agama Kristen) 5, no. 1 (2019): 36-53.

Kooman, W. J. Martin Luther. Jakarta: BPK Gunung Mulia, 1985.

Lumoindong, Gilbert. Dipilih Sebelum Dunia Dijadikan. Yogyakarta: Yayasan Andi, 2004. 
Manalu, Parluhutan. "Memahami Theologia Dalam Surat Titus." SOTIRIA (Jurnal Theologia dan Pendidikan Agama Kristen) 2, no. 1 (2019): 39-59. http://sttpaulusmedan.ac.id/ejournal/index.php/sotiria/index.

Munthe, Eben. "Implikasi Penggunaan 'El' Dan 'YHWH' Dalam Kekristenan Masa Kini." KURIOS (Jurnal Teologi dan Pendidikan Agama Kristen) 5, no. 1 (2019): 54-73.

Nixon, R. E. H. A. "Kemuliaan." Dalam Ensiklopedi Alkitab Masa Kini. Jilid. 2. Diterjemahkan oleh J. M. Pattiasina. Disunting oleh Oppusunggu. Jakarta: Yayasan Komunikasi Bina Kasih/OMF, 2004.

Nixon, R. E. Tafsiran Alkitab Masa Kini. Diterjemahkan oleh H. P. Nasution. Jakarta: Yanyasan Komunikasi Bina Kasih/OFM, 1999.

Packer, J. I. "Pilihan." Dalam Ensiklopedi Alkitab Masa Kini. Jilid. 2. Diterjemahkan oleh M. H. Simanungkalit. Jakarta: Yayasan Komunikasi Bina Kasi/OMF, 2004.

Pfeiffer, Charles F. Everett F. Horrison. Disunting oleh Tafsiran Alkitab Wycliffe. Malang: Gandum Mas, 2001.

Reinker, Frinz." $\alpha \kappa \lambda \varepsilon ́ \gamma \omega, "$ A Lingustic Key To The Greek New Testament. Grand Rapids: Zondervan Publishing House, 1980.

Sarumaha, Nurnilam. "Eskatologi Dalam Injil Markus." EPIGRAPHE: Jurnal Teologi dan Pelayanan Kristiani 1, no. 2 (2017): 104-118.

Siahaya, Karel Martinus, Johannis Siahaya, and Nunuk Rinukti. "Tuhan Ada Di Mana-Mana: Mencari Makna Bagi Korban Bencana Di Indonesia." KURIOS (Jurnal Teologi dan Pendidikan Agama Kristen) 6, no. 1 (2019): 103-113.

Soedarmo, R. Perjanjian Anugerah, Iktisar Dogmatika. Jakarta: BPK Gunung Mulia, 2001.

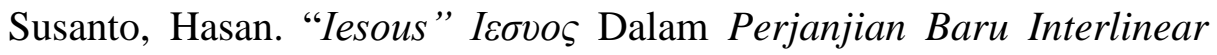
Dan Konkordasi. Jilid. 2. Jakarta: Lembaga Alkitab Indonesia, 2004.

Vine, W. E. Merril F. Ungen, William White, "Redeem." Complete Expocitory Dictionary Old and New Testament Word. Canada: Thomas Nelson Publisher, 1985. 
Wisman, D. J. A. R. Millard, "Meterai." Dalam Ensiklopedi Alkitab Masa Kini. Diterjemahkan oleh Soetarno. Jakarta: Yayasan Komunikasi Bina Kasih/OMF, 2004.

Woolley, R. A. “Allah Adalah Roh Sejati.” Dalam Ensiklopedi Alkitab Masa Kini. Diterjemahkan oleh J. M. Pattiasina. Jakarta: Yayasan Komunikasi Bina Kasih/OMF, 2004. 